\section{UPAYA PREVENTIF PEMERINTAH DALAM KASUS PELANGGARAN USAHA PERTAMBANGAN DI PROVINSI SULAWESI UTARA $^{1}$ \\ Oleh: Marcelino Yosua Maramis ${ }^{2}$}

\begin{abstract}
ABSTRAK
Tujuan dilakukannya penelitian yaitu untuk mengetahui apa saja pelanggaran pertambangan yang terjadi di Provinsi Sulawesi Utara dan bagaimana upaya preventif yang telah dilakukan pemerintah terhadap pertambangan di Provinsi Sulawesi Utara yang dengan menggunakan metode penelitian hukum normatif disimpulkan: 1 . Kegiatan usaha pertambangan yang dikelola baik oleh badan usaha, koperasi, maupun perseorangan baik yang berizin maupun yang tidak berizin pasti mempunyai kepentingannya sendiri - sendiri. Kepentingan inilah yang nantinya dapat menyebabkan terjadinya pelanggaran pertambangan karena adanya perbedaan kepentingan oleh para pihak dalam kegiatan usaha pertambangan. Pelanggaran pertambangan yang terjadi di Indonesia khsusunya yang ada di Provinsi Sulawesi Utara terbagi menjadi pelanggaran administratif dan tindakan pidana dalam lingkungan pertambangan. 2. Pemerintah dengan berpedoman pada peraturan perundang undangan yang berlaku telah melakukan upaya preventif seperti memberikan sosialisasi mengenai pertambangan kepada masyarakat, memberikan kepastian hukum kepada masyarakat, dan melakukan pengawasan terhadap pertambangan - pertambangan yang ada untuk mencegah pelanggaran pelanggaran pertambangan terjadi atau paling tidak mengurangi potensi terjadinya pelanggaran pertambangan yang terulang ulang.

Kata kunci: pertambangan; Sulawesi utara;
\end{abstract}

\section{PENDAHULUAN}

\section{A. LATAR BELAKANG}

Izin Usaha Pertambangan (IUP) dapat diperoleh dari Menteri atau Gubernur karena telah diberikan wewenang oleh Undang -

\footnotetext{
${ }^{1}$ Artikel Skripsi. Dosen Pembimbing: Prof. Dr. Ronald J. Mawuntu, SH, MH; Henry R. Ch. Memah, SH, MH

2 Mahasiswa pada Fakultas Hukum Unsrat, NIM : 16071101145
}

undang No.23 Tahun 2014 tentang Pemerintah Daerah (UU Pemda). Ada 5 kriteria yang dijadikan bahan evaluasi penerbitan IUP, yaitu Kriteria Administratif, Kriteria Kewilayahan, Kriteria Teknis, Kriteria Lingkungan, dan Kriteria Finansial.

Seiring berjalannya waktu, usaha pertambangan di Indonesia menjadi semakin banyak, salah satunya pertambangan yang berada di Sulawesi Utara. Banyak usaha pertambangan yang tersebar di Sulawesi Utara, khususnya pertambangan emas yang menjadikan Sulawesi Utara disebut sebagai "Surga Tambang Emas". Data potensi Sumber Daya Mineral dan Migas Provinsi Sulawesi Utara, emas yang terdata kurang lebih $51,150,448$ ton tersebar di wilayah Minahasa Selatan, Minahasa Tenggara, Minahasa Utara, dan Bolaang Mongondow Raya. ${ }^{3}$ Pertambangan - pertambangan ini dikelola baik oleh perusahaan pertambangan maupun yang dikelola oleh penduduk sekitar area pertambangan. Keberadaan tambang emas ini dapat mempunyai dampak Positif dan dampak Negatif.

\section{B. Rumusan Masalah}

1. Apa saja pelanggaran pertambangan yang terjadi di Provinsi Sulawesi Utara?

2. Bagaimana upaya preventif yang telah dilakukan pemerintah terhadap pertambangan di Provinsi Sulawesi Utara?

\section{Metode Penelitian}

Metode penelitain yang digunakan dalam penulisan skripsi ini menggunakan metode penelitian hukum normatif.

\section{PEMBAHASAN}

\section{A. Pelanggaran - Pelanggaran Pertambang di Provinsi Sulawesi Utara \\ Pelanggaran pertambangan yang terjadi di Provinsi Sulawesi Utara telah ada sejak lama, berikut beberapa kasus pelanggaran}

\footnotetext{
3 Tribun Sulut, "Daftar Perusahaan Tambang Beroperasi di Sulawesi Utara, Ternyata Sulut 'Surga' Tambang Emas", https://manado.tribunnews.com/amp/2019/02/27/daftar -perusahaan-tambang-beroperasi-di-sulawesi-utaraternyata-sulut-surga-tambang-emas, terakhir diakses 13 November 2019.
} 
pertambangan yang pernah terjadi di Provinsi Sulawesi Utara:

1. Pada tahun 2004, PT. Newmont Minahasa Raya (PT. NMR) terindikasi melakukan pelanggaran terhadap perizinan pengelolaan tailing sebagai limbah $\mathrm{B}^{4}$. Ini merupakan pelanggaran pasal 104 UU No. 32 tahun 2009 tentang Perlindungan dan Pengolahan Lingkungan Hidup, yang berisi "Setiap orang yang melakukan pengelolaan limbah B3 tanpa izin sebagaimana dimaksud dalam pasal 59 ayat (4), dipidana dengan pidana penjara paling singkat 1 (satu) tahun dan paling lama 3 (tiga) tahun dan denda paling sedikit Rp.1.000.000.000,00 (satu miliar rupiah) dan paling banyak Rp.3.000.000.000,00 (tiga miliar rupiah).

2. Pada tahun 2018 , tercatat terdapat tujuh pertambangan liar di Ratatotok Minahasa Tenggara. "Ada tujuh lokasi penambangan yang dikunjungi tim gabungan Pemerintah Kabupaten Mitra, lima diantaranya dinyatakan sudah melapor ke pihak Provinsi Sulut, namun masih akan mengurus ijin penambangan. Itu pun belum termasuk sejumlah lokasi penambangan lainnya yang beredar diwilayah pertambangan Alazon Ratatotok" ujar Sumual. ${ }^{5}$ Pertambangan - pertambangan ini tentu tidak memiliki izin pertambangan dan telah melanggar UU No.4/2009 dan Perda Sulut No.3/2019. Kemudian limbah yang dihasilkan juga tentu dibuang ke sembarang tempat oleh pengelolah tambang karena tidak ada pengawasan dari pemerintah.

3. Pertambangan illegal desa Bakan, Bolaang Mongondow. Sebenarnya pertambangan illegal di Bolaang Mongondow, khususnya pertambangan

\footnotetext{
${ }^{4}$ Detiknews, "Cukup bukti pemerintah \& Newmont telah cemari Buyat",

http://news.detik.com/berita/239260/cukup-buktipemerintah-newmont-vemari-buyat, terakhir diakses 18 Januari 2020.

${ }^{5}$ ManadoLine, "Kekayaan alam Mitra "Dirampok" banyak perusahaan tambang emas illegal", https://manadoline.com/kekayaan-alam-mitra-dirampokbanyak-perusahaan-tambang-emas-ilegal/, terakhir diakses 18 januari 2020.
}

yang ada di desa Bakan telah diawasi dan ditutup oleh pemerintah sejak tahun 2017 karena mangakibatkan tanah longsor di area pertambangan yang menewaskan 6 orang penambang. Tapi sampai tahun 2019, masyarakat sekitar masih terus melakukan kegiatan pertambangan illegal di area tersebut yang akhirnya banyak memakan korban. Tercatat pada bulan Februari tahun 2019 terjadi kembali tanah longsor di area pertambangan yang menewaskan 21 orang penambang, kemudian pada bulan April tahun 2019 terjadi kecelakan pada saat melakukan kegiatan pertambangan yang mengakibatkan 1 orang penambang tewas, dan terakhir pada bulan Juli 2019 kembali terjadi kecelakan pada saat melakukan kegiatan pertambangan yang mengakibatkan 2 orang penambang tewas.

Terdapat beberapa alasan kegiatan pertambangan ilegal di Bolaang Mongondow tetap dijalankan oleh masyarakat walaupun telah ditutup oleh pemerintah. Alasan - alasan tersebut adalah:

a. Tidak disediakannya Wilayah Pertambangan Rakyat oleh pemerintah daerah maupun pemerintah pusat;

b. Lambatnya penanganan kebutuhan yang dibutuhkan masyarakat oleh pemerintah;

c. Kegiatan pertambangan telah menjadi mata pencaharian masyarakat sejak dahulu.

Selain pelanggaran - pelanggaran pertambangan yang pernah terjadi di Provinsi Sulawesi Utara, pemerintah juga telah menetapkan pelanggaran - pelanggaran pertambangan yang terbagi menjadi pelanggaran administrasi dan pelanggaran pidana dan telah di tuangkan dalam UU Nomor 4 Tahun 2009 tentang Pertambangan Mineral dan Batubara serta dalam Peraturan daerah Provinsi Sulawesi Utara Nomor 3 tahun 2019 tentang Pertambangan Mineral.

1. Pelanggaran Administrasi

Indonesia merupakan Negara dengan kekayaan Sumber daya Alam yang melimpah sehingga banyak masyarakat Indonesia bahkan pihak - pihak dari Negara lain yang ingin mengambil keuntungan dari sumber daya alam yang ada di Negara ini. 
Maka memungkinkan adanya pihak yang mencoba melakukan usaha pertambangan tanpa mengikuti peraturan yang ada untuk mendapatkan keuntungan yang lebih besar. Hal ini merupakan pelanggaran usaha pertambangan karena melanggar apa yang telah di atur oleh Peraturan Daerah Sulawesi Utara No.3 tahun 2019 dan bertolak belakang dengan Undang - Undang Dasar Negara Republik Indonesia Tahun 1945 Pasal 33.

Menurut Peraturan Daerah Sulawesi Utara No.3 Tahun 2019 tentang Pertambangan Mineral, bahwa yang dikatakan melanggar dan dapat dikenakan sanksi administrasi adalah setiap orang atau badan hukum yang melanggar ketentuan sebagaimana dimaksud dalam pasal 25 ayat (4) dan ayat (5), pasal 27, pasal 31 ayat (5) dan ayat (6), pasal 39 , pasal 47 ayat (1), pasal 50 ayat (2), pasal 51, pasal 52, pasal 53, pasal 57 dan pasal 59. ${ }^{6}$

a. Kewajiban menjaga mineral lain

Dalam pasal 25 ayat (4) Peraturan Daerah Provinsi Sulawesi Utara Nomor 3 Tahun 2019 tentang pertambangan mineral menyebutkan "Dalam hal pemegang IUP tidak mengusahakan mineral lain sebagaimana dimaksud pada ayat (3), wajib menjaga mineral lain yang ditemukan." ${ }^{7}$

Artinya pelaku usaha pertambangan pememegang IUP yang tidak mengusahakan mineral lain selain mineral yang dicari oleh pelaku usaha tersebut wajib untuk menjaga mineral tersebut agar mineral yang ditemukan tidak dirusak baik oleh pelaku usaha pertambangan maupun oleh pihak lain.

b. Pertambangan setelah pengangkatan Kepala Teknik Tambang

Dalam pasal 25 ayat (5) Peraturan Daerah Provinsi Sulawesi Utara Nomor 3 tahun 2019 tentang pertambangan mineral menyebutkan "Pemegang IUP dilarang melakukan kegiatan usaha pertambangan sebelum mendapat pengesahan pengangkatan Kepala Teknik

6 Republik Indonesia, Peraturan Daerah Sulawesi Utara Nomor 3 Tahun 2019, tentang Pertambangan Mineral, pasal 75 ayat 1 .

7 Ibid, pasal 25 ayat (4).
Tambang dari Dinas Energi dan Sumber Daya Mineral Daerah Provinsi sesuai kewenangannya." ${ }^{8}$

Artinya pelaku usaha pertambangan pemegang IUP yang melakukan kegiatan usaha pertambangan sebelum adanya pengangkatan Kepala Teknik Tambang akan dianggap sebagai pertambangan illegal.

c. Pelaporan penemuan mineral

Dalam pasal 27 Peraturan Daerah Provinsi Sulawesi Utara Nomor 3 Tahun 2019 tentang pertambangan mineral menyebutkan "Dalam hal pemegang IUP Eksplorasi mendapatkan mineral yang tergali dalam kegiatan eksplorasi dan / atau kegiatan studi kelayakan, pemegang IUP Eksplorasi wajib melapor kepada Dinas."

Maksud dari pasal 27 Perda Provinsi Sulawesi Utara mengenai pertambangan mineral yaitu, pemegang IUP Eksplorasi pada saat kegiatannya menemukan mineral yang telah digali, wajib melaporkannya kepada Dinas untuk ditindak lanjuti.

d. Pemberian satu izin khusus pertambangan

Dalam pasal 31 ayat (5) Peraturan Daerah Sulawesi Utara No. 3 tahun 2019 tentang pertambangan mineral menyebutkan "setiap perusahaan sebagaimana dimaksud pada ayat (2), ayat (3), dan ayat (4) hanya dapat diberikan 1 (satu) jenis izin khusus dibidang pertambangan mineral." ${ }^{\prime 10}$

Maksud dari pasal ini ialah pelaku usaha pertambangan hanya dapat memperoleh satu izin khusus pertambangan diantara izin sementara untuk melakukan pengangkutan dan penjualan, IUP Operasi Produksi Khusus untuk penjualan, IUP Operasi Khusus untuk pengangkutan dan penjualan, dan IUP Operasi Produksi Khusus untuk pengolahan dan / atau pemurnian.

e. Satu izin khusus pertambangan untuk satu jenis izin khusus pertambangan

\footnotetext{
8 Loc. Cit.

${ }^{9} \mathrm{Ibid}$, pasal 27.

$10 \mathrm{Ibid}$, pasal 31 ayat (5).
} 
Dalam pasal 31 ayat (6) Peraturan Daerah Sulawesi Utara No.3 Tahun 2019 tentang pertambangan mineral menyebutkan "Setiap perusahaan sebagaimana dimaksud pada ayat (2), ayat (3), dan ayat (4) tidak boleh memiliki lebih dari 1 (satu) izin dari masing masing jenis izin khusus dibidang pertambangan mineral yang dikeluarkan oleh Pemerintah Daerah." ${ }^{11}$

Artinya pelaku usaha pertambangan tidak dapat memiliki lebih dari satu izin khusus pertambangan dengan jenis izin pertambangan khusus yang sama seperti memiliki 2 (dua) IUP Operasi Produksi Khusus untuk penjualan.

f. Kewajiban meningkatkan nilai tambah mineral

Dalam pasal 39 Peraturan Pemerintah Provinsi Sulawesi Utara No.3 tahun 2019 tentang pertambagan mineral menjelaskan bahwa pelaku saha pertambangan mempunyai kewajiban untuk melakukan tahapan pengolahn dan pemurnian bahan tambang yang diproduksi untuk meningkatkan nilai tambah mineral sebelum dilakukan pengankutan bahan tambang untuk dijual.

g. IUP hanya berlaku pada pihak pertama Dalam pasal 47 ayat (1) Peraturan Daerah Provinsi Sulawesi Utara Nomor 3 tahun 2019 tentang pertambangan mineral meyebutkan "Pemegang IUP mineral tidak boleh memindahkan kepemilikan IUP kepada pihak lain." ${ }^{12}$

Artinya Izin Usaha Pertambangan mineral yang dimiliki oleh suatu perusahan pertambangan hanya berlaku untuk perusahan pertambangan tersebut dan IUP mineral tidak dapat dipindah tangankan kepada pihak lain.

h. Penempatan kegiatan usaha pertambangan

Dalam pasal 50 ayat (2) Peraturan Daerah Provinsi Sulawesi Utara Nomor 3 tahun 2019 tentang Pertambangan Mineral menyebutkan "Kegiatan usaha pertambangan untuk mineral tidak dapat dilaksanakan pada tempat yang dilarang untuk melakukan kegiatan usaha pertambangan." ${ }^{13}$

Maksud dari pasal ini ialah kegiatan usaha pertambangan dilakukan ditempat yang telah disetujui oleh pemerintah dan tidak dilakukan ditempat yang dilarang seperti dekat dengan perumahan rakyat, di daerah hutan lindung, maupun dekat dengan area perkotaan.

i. Izin dari pemegang hak atas tanah Sesuai dengan pasal 51 Peraturan Daerah Provinsi Sulawesi Utara Nomor 3 tahun 2019, bahwa kegiatan usaha pertambangan yang telah diberikan izin oleh pemerintah baru dapat dilakukan apabila telah mendapatkan izin dari pemegang hak atas tanah yang akan dijadikan tempat kegiatan usaha pertambangan.

j. Penyelesaian HAK pemegang hak atas tanah

Sesuai Perda Sulawesi Utara tentang pertamabangan mineral pasal 52 bahwa sebelum menyelesaikan kegiatan usaha pertambangan, pemegang IUP Operasi Produksi wajib menyelesaikan hak atas tanah dan memberikan kompensasi kepada pemegang ha katas tanah.

k. Penggunaan jasa pertambangan local

Dalam Perda Sulawesi Utara mengenai pertambangan mineral pasal 53 mengatur mengenai pemegang IUP wajib menggunakan jasa pertambangan local yang berada di daerah tersebut dan apabila tidak terdapat jasa pertambangan di daerah tersebut maka pemegang IUP dapat menggunakan jasa pertambangan lain yang berbadan hukum Indonesia.

I. Kewajiban pembayaran pendapatan Daerah

Sesuai dengan Perda Sulawesi Utara mengenai pertambangan mineral pasal 57, pemegang IUP wajib membayar pendapatan daerah dan penerimaan Negara bukan pajak sesuai ketentuan perundang - undangan yang berlaku. Kemudian pemegang IUPK Operasi produksi wajib melaksanakan tanggung

\footnotetext{
11 Loc. Cit.

12 Ibid, pasal 47 ayat (1).
}

\footnotetext{
$13 \mathrm{lbid}$, pasal 50 ayat (2).
} 
jawab social dan lingkungan dengan memperhatikan kepatutan dan kewajaran sesuai dengan ketentuan perundang - undangan.

m. Pelunasan biaya pencadangan wilayah dan pencetakan peta

Dalam Peraturan Daerah Provinsi Sulawesi Utara Nomor 3 tahun 2019 tentang pertambangan mineral pasal 59 menyebutkan "Data dan informasi sistem informasi geografis hasil inventarisasi, penyelidikan umum dan penelitian serta eksplorasi sebagaimana dimaksud dalam pasal 58 ayat (1) dan (3) huruf d memiliki nilai biaya pencadangan wilayah dan biaya pecetakan peta yang harus dibayar oleh pemohon WIUP." ${ }^{14}$

Sesuai dengan Perda Sulawesi Utara tentang pertambangan mineral pasal 59, pemohon WIUP berkewajiban membayar biaya pencadangan wilayah dan biaya pencetakan peta kepada pemerintah Daerah

Seperti yang telah disinggung di atas bahwa pemegang Izin Pertambangan Rakyat (IPR), Izin Usaha Pertambangan (IUP), dan Izin Usaha Pertambangan Khusus (IUPK) akan dikenakan sanksi administrasi apabila melakukan pelanggaran - pelanggaran yang terdapat dalam Peraturan Daerah Provinsi Sulawesi Utara Nomor 3 tahun 2019 tentang pertambangan mineral pasal 75 .

Sanksi administrasi tersebut berupa:

1) Teguran tertulis;

2) Penghentian sementara sebagian atau seluruh kegiatan usaha;

3) Pembekuan izin;

4) Pencabutan izin;

5) Penetapan ganti rugi; dan

6) Denda. ${ }^{15}$

Dalam pasal 151 ayat (1) undang - undang no.4 tahun 2009 tentang Pertambangan Mineral dan Batubara, terdapat beberapa pelanggaran administratif lain seperti melanggarar pasal 96 mengenai kewajiban melaksanakan kaidah teknik pertambangan yang baik, pasal 97 mengenai kewajiban menjamin penerapan standard dan baku

\footnotetext{
14 Republik Indonesia, Peraturan Daerah Provinsi Sulawesi Utara Nomor 3 Tahun 2019, Op. Cit, pasal 59.

$15 \mathrm{Ibid}$, pasal 75 ayat (2)
}

mutu lingkungan sesuai dengan karakteristik suatu daerah, dan lain - lain.

2. Tindakan Pidana

Peraturan Daerah Provinsi Sulawesi Utara No.3 tahun 2019 tentang Pertambangan Mineral mengatur mengenai pelanggaran pidana yang terdapat dalam pasal 76 , yaitu melakukan kegiatan pertambangan tanpa izin, dan melakukan kegiatan pengolahan dan pemurnian dan/atau pengangkutan dan penjualan dari hasil penambangan yang tidak memiliki IUP, IPR, atau IUPK.

Selain pelanggaran pidana yang tertulis dalam Perda Pertambangan Mineral Sulut, Undang - Undang No.4 Tahun 2009 mengatur mengenai pemberian sanksi pidana terhadap pihak - pihak yang melakukan tindak pidana dalam usaha pertambangan. Tindakan - tindakan pidana yang dimaksud seperti melakukan pertambangan tanpa izin, penyampaian data laporan yang tidak benar, melakukan eksplorasi tanpa izin, kegiatan operasi produksi tanpa izin, dan menghalangi usaha pertambangan yang mempunyai izin.

a. Pertambangan Tanpa Izin

Dalam pasal 158 Undang - Undang No.4

Tahun 2009 dijelaskan bahwa "Setiap orang yang melakukan penambangan tanpa IUP, IPR, atau IUPK Sebagaimana dimaksud dalam pasal 37 , pasal 40 ayat (3), pasal 48, pasal 67 ayat (1), pasal 74 ayat (1) atau ayat (5) dipidana dengan pidana penjara 10 (sepuluh) tahun dan denda paling banyak Rp. 10.000.000.000,00 (Sepuluh Miliar Rupiah)." ${ }^{16}$

Dalam pasal tersebut telah dijelaskan sampai akibat hukum yang akan diterima bila melakukan pertambangan illegal atau tanpa adanya Izin Usaha Pertambangan (IUP), Izin Pertambangan Rakyat (IPR), atau Izin Usaha Pertambangan Khusus (IUPK).

Merupakan hal yang sangat penting untuk memperoleh IUP, IPR, atau IUPK dalam kegiatan usaha pertambangan yang dilakukan, karena penerbitan Izin Usaha ini memerlukan sayarat - sayarat vital yang harus dipenuhi oleh badan

${ }_{16}$ Republik Indonesia, Undang - Undang Nomor 4 Tahun 2009, Op. Cit, pasal 158. 
usaha, koperasi, atau perseorangan yang akan melakukan usaha pertambangan di Indonesia.

Dalam Peraturan Pemerintah Republik Indonesia Nomor 23 Tahun 2010 tentang Pelaksanaan Kegiatan Usaha Pertambangan Mineral dan Batu Bara telah dijelaskan sayarat - syarat memperoleh IUP, IPR, dan IUPK

Dalam Pasal 23, syarat pemberian suatu IUP eksplorasi dan IUP operasi Produksi, meliputi:

1) Persyaratan Administrasi,

2) Persyaratan Teknis,

3) Persyaratan Lingkungan, dan

4) Persyaratan Finansial

Dalam Pasal 48, untuk mendapatkan Izin Pertambangan Rakyat (IPR), pemohon harus memenuhi:

1) Persyaratan administratif,

2) Persyaratan teknis, dan

3) Persyaratan finansial.

Dalam pasal 63 , persyaratan yang harus dipenuhi untuk memperoleh IUPK eskplorasi dan IUPK operasi produksi, yaitu:

1) Persyaratan administratif,

2) Persyaratan teknis,

3) Persyaratan lingkungan, dan

4) Persyaratan finansial

Apabila suatu perusahaan atau kelompok masyarakat melakukan kegiatan pertambangan tanpa ada izin usaha pertambangan sah yang dikeluarkan oleh pemerintah, yaitu izin pertambangan yang telah ditulis diatas. Maka kegiatan pertambangan tersebut dapat mengakibatkan kerusakan lingkungan berkepanjangan di area sekitar pertambangan dan bahkan dapat mengakibatkan para penambang mengalami kecelakan saat melakukan kegiatan pertambangan dikarenakan area pertambangan yang tidak layak untuk dijadikan tempat untuk melakukan kegiatan pertambangan.

Seperti yang terjadi di pertambangan emas ilegal yang ada di Bolaang Mongondow, Sulawesi Utara pada Februari 2019, yang mengakibatkan tanah longsor di area pertambangan sehingga dikabarkan puluhan masyarakat yang sedang melakukan kegiatan pertambangan illegal diarea tersebut tertumbun tanah longsor.

b. Penyampaian Data atau Laporan yang Tidak Benar

Dalam melakukan kegiatan pertambangan, badan usaha, koperasi, atau perseorangan harus membuat data yang akurat dan tidak dengan sengaja mengubah data yang sebenarnya. Data data yang dimaksud seperti data studi kelayakan, laporan kegiatan usaha dan laporan penjualan hasil tambang. Laporan atau data - data ini dibuat agar pelaku usaha pertambangan dapat mempertanggungjawabkan kegiatan usaha pertambangannya.

"Pemegang IUP, IPR, atau IUPK yang dengan sengaja menyampaikan laporan sebagaimana dimaksud dalam pasal 43 ayat (1), pasal 70 huruf e, pasal 81 ayat (1), pasl 105 ayat (4), pasal 110, pasal 111 ayat (1) dengan tidak benar atau menyampaikan keterangan palsu dipidana dengan pidana penjara paling lama 10 (sepuluh) tahun dan denda paling banyak Rp. 10.000.000.000,00 (Sepuluh Miliar Rupiah). ${ }^{17}$

c. Kegiatan Eksplorasi Pertambangan tanpa Izin

Sesuai Dengan Undang - Undang yang berlaku, bahwa kegiatan pertambangan harus mempunyai Izin Usaha Pertambangan (IUP) atau Izin Usaha Pertambangan Khusus (IUPK). Maka apabila ada badan usaha, koperasi, atau perorangan yang melakukan kegiatan eksplorasi pertambangan tanpa adanya IUP atau IUPK, akan dipidana sesuai Undang - Undang yang berlaku, yaitu Undang - Undang No.4 Tahun 2009 Pasal 160 ayat (1) "Setiap orang yang melakukan kegiatan eksplorasi tanpa memiliki IUP atau IUPK sebagaimana dimaksud dalam pasal 37 atau pasal 74 ayat (1) dipidana dengan pidana kurungan paling lama 1 (satu) tahun atau denda paling banyak Rp. 200.000.000,00 (Dua Ratus Juta Rupiah)." ${ }^{18}$

17 Republik Indonesia, Undang - Undang Nomor 4 Tahun 2009, Op. Cit, pasal 159.

$18 \mathrm{lbid}$, pasal 160 ayat (1). 
Hal ini memiliki perbedaan dengan poin pertama, melakukan kegitan pertambangan tanpa adanya Izin Usaha Pertambangan (IUP), Izin Pertambangan Rakyat (IPR), atau Izin Usaha Pertambangan Khsusu (IUPK). Yaitu dalam poin yang pertama dipidana dekarenakan badan usaha, koperasi, atau perorangan yang melakukan usaha pertambangan telah melakukan semua tahapan dalam kegiatan usaha pertambangan (Pasal 1 ayat (6)). Sedangkan dalam Pasal 160 dipidana karena telah melakukan kegiatan eksplorasi tanpa izin namun belum sampai pada tahapan - tahapan yang selanjutnya.

d. Kegiatan Operasi Produksi tanpa Izin Izin Usaha Pertambangan (IUP) terbagi dalam dua tahap sesuai dalam pasal 36 UU Minerba, yaitu:

1) IUP Eksplorasi meliputi kegiatan penyelidikan umum, eksplorasi, dan studi kelayakan;

2) IUP Operasi Produksi meliputi kegiatan konstruksi, penambangan, pengolahan dan pemurnian, serta pengangkutan dan penjualan.

Meski badan usaha, koperasi, atau perorangan yang melakukan usaha pertambangan telah memperoleh Izin Usaha Pertambangan (IUP) Eksplorasi, namun tetap tidak dapat melanjutkan ke kegiatan konstruksi hingga penjualan apabila belum mendapatkan Izin Usaha Pertambangan (IUP) Operasi Produksi, meskipun dalam pasal 46 UU No.4 tahun 2009 telah menjelaskan bahwa pemegang IUP Eksplorasi dijamin untuk memperoleh IUP Operasi Produksi untuk melanjutkan kegiatan pertambangannya atas hasil pelelangan Wilayah Izin Usaha Pertambangan (WIUP) mineral logam atau batu bara yang telah mempunyai data hasil kajian studi kelayakan.

Apabila Badan Usaha, Koperasi, atau perseorangan yang melakukan usaha pertambangan tetap memaksakan diri melakukan kegiatan operasi produksi tanpa adanya IUP Operasi Produksi maka akan dikenakan hukuman pidana sesuai dengan Pasal 160 ayat (2) "Setiap orang yang mempunyai IUP Eksplorasi tetapi melakukan kegiatan operasi produksi dipidana dengan pidana penjara paling lama 5 (lima) tahun dan denda paling banyak Rp. 10.000.000.000,00 (Sepuluh Miliar Rupiah)." ${ }^{19}$

e. Menghalangi Kegiatan Usaha Pertambangan

Apabila dalam suatu kegiatan usaha pertambangan yang telah mimiliki Izin Usaha Pertambangan diganggu atau dihalangi oleh masyarakat sekitar yang mungkin merasa dirugikan atau adanya gangguan dari pihak yang lain yang merugikan badan usaha, koperasi, atau perorangan yang sedang melakukan kegiatan pertambangan, dapat dipidana sesuai dengan pasal 162 Undang Undang No.4 Tahun 2009, yaitu "Setiap orang yang merintangi atau mengganggu kegiatan usaha pertambangan dari pemegang IUP atau IUPK yang telah memenuhi syarat - syarat sebagaimana dimaksud dalam pasal 136 ayat (2) dipidana dengan pidana kurungan paling lama 1 (Satu) tahun atau denda paling banyak 100.000.000,00 (Seratus Juta Rupiah)." 20

Selain hukuman pidana yang ada pada pasal 158, pasal 159, pasal 160, pasal 161, dan pasal 162 UU Minerba, Pelaku tindakan pidana dibidang pertambangan juga dapat dijatuhi pidana tambahan, berupa:

1) Perampasan barang yang digunakan dalam melakukan tindakan pidana;

2) Perampasan keuntungan yang diperoleh dari tindak pidana; dan/atau

3) Kewajiban membayar biaya yang timbul akibat tindak pidana.

Kemudian dalam pasal 163 ayat (1) dan ayat (2) Undang - Undang No.4 Tahun 2009, untuk badan hukum yang melakukan tindakan pidana dalam kegiatan pertambangan, selain pidana penjara dan denda, badan hukum juga dapat dijatuhi hukuman denda dengan pemberatan tambahan $1 / 3$ (Satu per Tiga) kali dari ketentuan maksimum

19 Loc. Cit.

20 Loc. Cit. 
pidana denda yang dijatuhkan dan dapat dijatuhi pidana tambahan berupa:

1) Pencabutan izin usaha; dan/atau

2) Pencabutan status badan hukum.

\section{B. Upaya Preventif Pemerintah Sulawesi Utara}

Dalam rangka mencegah terjadinya pelanggaran pertambangan yang ada di Indonesia khususnya di daerah Sulawesi Utara, pemerintah Sulawesi Utara tentu telah melakukan upaya - upaya pencegahan dengan berpedoman pada peraturan perundang undangan yang berlaku.

Upaya - upaya pencegahan yang dimaksud berupa sosialisasi kepada masyarakat, memberikan kepastian hukum, serta adanya pembinaan dan pengawasan kegiatan pertambangan di Sulawesi Utara.

1. Sosialisasi Pelanggaran Pertambangan

Untuk mencegah bertambahnya pelanggaran pertambangan seperti pertambangan illegal, pemerintah provinsi dalam hal ini Dinas ESDM (Energi Sumber Daya Mineral) Sulawesi Utara melakukan sosialisasi kepada masyarakat Sulawesi Utara, khususnya masyarakat yang berada di area dekat pertambangan atau dekat dengan sumber bahan tabang mineral, agar tidak melakukan pertambangan tanpa ada izin dari pemerintah yang berwenang, serta sosialisasi tata cara memperoleh izin usaha kegiatan pertambangan.

Pertambangan yang tidak mempunyai izin tentu tidak memenuhi syarat - syarat yang telah diatur seperti persyaratan administrasi, persyaratan teknis, persyaratan lingkungan, dan persyaratan finansial.

Pertambangan illegal tentu akan berdapak negatif baik kepada penambang yang dapat mengalami kecelakaan seperti tertimbun saat sedang melakukan kegiatan pertambangan tanpa adanya peralatan tambang yang memadai, kemudian berdampak pada lingkungan sekitar area tambang yang dapat mengalami pencemaran lingkungan akibat aktifitas pertambangan illegal tanpa adanya pengelolaan lebih lanjut pada lingkungan sekitar tambang hingga akhirnya akan berpengaruh pada generasi berikutnya.
Pada 05 Meret 2019 CNN Indonesia mewawancarai Kepala Dinas ESDM Sulut Adrianus $B$. Tinungki sehubungan dengan kejadian tanah longsor di tempat pertambangan illegal yang berada di Kecamatan Bolaang Mongondow. Adrianus mendapatkan laporan dari stafnya bahwa belum seminggu kejadian tanah longsor di tambang illegal Bolmong, sudah ada warga yang kembali ke tambang tersebut untuk mengumpulkan batu yang mengandung emas. Menurut data dari Asosiasi Penambang Rakyat Indonesia (APRI), setidaknya terdapat 10 ribu penambang illegal di Sulawesi Utara. ${ }^{21}$

Oleh karena hal tersebut pemerintah perlu lebih giat dalam mengadakan sosialisasi kepada masyarakat terutama yang belum mengetahui aturan hukum pertambangan, khusnya Perda Sulut yang terbaru tentang Pertambangan Mineral, bahwa sangat berbahaya apabila melakukan kegiatan pertambangan illegal.

2. Kepastian Hukum

Sebelum Peraturan Daerah Provinsi Sulawesi Utara No.3 Tahun 2019 tentang Pertambangan Mineral dibuat dan diterapkan kepada masyarakat, aturan mengenai pertambangan di Sulawesi Utara menggunakan Undang - Undang No.4 Tahun 2009 tentang Pertambangan Mineral dan Batubara.

Namun sebagai daerah otonom, Sulawesi Utara perlu mengeluarkan peraturan daerahnya sendiri guna mengatur dan mengawasi pertambagan di Sulawesi Utara namun tentu saja disesuaikan dengan Undang - Undang No.4 Tahun 2009 tentang Pertambangan Mineral. Maka Peraturan Daerah Sulawesi Utara No.3 Tahun 2019 tentang Pertambangan Mineral dibuat dan di sahkan.

Disahkannya Perda Sulut ini, merupakan upaya Pemerintah Daerah Sulawesi Utara untuk memberikan kepastian hukum kepada masyarakat, artinya pertambangan yang dilakukan di daerah Sulawesi Utara ini

21 CNN Indonesia, "Pemda Sulut akui sulit berantas tambang illegal", https://www.cnnindonesia.com/ekonomi/201903041836 49-85-374460/pemda-sulut-akui-sulit-berantas-tambangilegal, terakhir diakses 15 November 2019. 
apabila dijalankan dengan legal atau sah maka akan akan mendapat jaminan oleh pemerintah Provinsi Sulawesi Utara. Kemudian Peraturan Daerah ini dibuat guna mencegah pelanggaran pertambangan yang semakin banyak, dan berharap pertambangan yang melakukan pelanggaran pertambangan agar perlahan - lahan dapat berkurang.

3. Pembinaan dan Pengawasan

Adanya pembinaan dan pengawasan oleh pemerintah Daerah kepada Pertambangan yang berlokasi di daerah Sulawesi Utara merupakan hal yang penting untuk kebaikan bersama.

a. Pembinaan Pertambangan

Sesuai dengan Peraturan Daerah Sulawesi Utara yang mengatur mengenai Pertambangan Mineral, bahwa pemerintah daerah dalam hal ini Gubernur memberikan pembinaan terhadap penyelenggaraan pengelolaan usaha pertambangan mineral yang dilaksanakan oleh pemegang IUP dan IUPK.

Pembinaan terhadap penyelenggaraan pengelolaan usah pertambangan terdiri atas:

1) Pemberian pedoman dan standar pelaksanaan pengelolaan usaha pertambangan;

2) Pemberian bimbingan, supervisi, dan konsultasi;

3) Pendidikan dan Pelatihan; dan

4) Perencanaan, penelitian, pengembangan, pemantauan, dan evaluasi pelaksanaan penyelenggaraan usaha pertambangan dibidang mineral dan batubara. ${ }^{22}$

b. Pengawasan Pertambangan

Dalam pasal 72 Peraturan Daerah Sulawesi Utara No.3 Tahun 2019 tentang Pertambangan Mineral, pengawasan terhadap penyelenggaraan pengelolaan usaha pertambangan dilaksanakan oleh inspektur tambang dan pejabat yang ditunjuk oleh Gubernur.

1) Pengawasan yang dilakukan oleh Inspektur Tambang yaitu:

${ }^{22}$ Republik Indonesia, Peraturan Daerah Provinsi Sulawesi Utara No.3 Tahun 2009,Op. Cit, pasal 66 ayat (2) a) Teknis pertambangan;

b) Konservasi sumber daya mineral;

c) Keselamatan dan kesehatan kerja pertambangan;

d) Keselamatan operasi pertambangan;

e) Pengelolaan lingkungan hidup, reklamasi dan pascatambang; dan

f) Pemanfaatan barang, jasa teknologi dan kemampuan rekayasa serta rancangan bangun dalam negeri.

2) Pengawasan yang dilakukan oleh Pejabat yang ditunjuk oleh Gubernur yaitu:
a) Pemasaran;
b) Keuangan;
c) Pengelolaan data mineral;
d) Pengembangan tenaga kerja teknis pertambangan;
e) Pengembangan dan pemberdayaan masyarakat setempat;
f) Penguasaan, pengembangan dan penerapan teknologi pertambangan;
g) Kegiatan lain dibidang kegiatan usaha pertambangan yang menyangkut kepentingan umum;
h) Pelaksanaan kegiatan sesuai IUP, IPR, IUPK; dan
i) Jumlah teknis dan mutu hasil usaha pertambangan. ${ }^{23}$

\section{PENUTUP}

\section{A. Kesimpulan}

1. Kegiatan usaha pertambangan yang dikelola baik oleh badan usaha, koperasi, maupun perseorangan baik yang berizin maupun yang tidak berizin pasti mempunyai kepentingannya sendiri sendiri. Kepentingan inilah yang nantinya dapat menyebabkan terjadinya pelanggaran pertambangan karena adanya perbedaan kepentingan oleh para pihak dalam kegiatan usaha pertambangan. Pelanggaran pertambangan yang terjadi di Indonesia khsusunya yang ada di Provinsi Sulawesi Utara terbagi menjadi pelanggaran administratif dan tindakan pidana dalam lingkungan pertambangan.

2. Pemerintah dengan berpedoman pada peraturan perundang - undangan yang berlaku telah melakukan upaya preventif

23Ibid, pasal 72 
seperti memberikan sosialisasi mengenai pertambangan kepada masyarakat, memberikan kepastian hukum kepada masyarakat, dan melakukan pengawasan terhadap pertambangan - pertambangan yang ada untuk mencegah pelanggaran pelanggaran pertambangan terjadi atau paling tidak mengurangi potensi terjadinya pelanggaran pertambangan yang terulang - ulang.

\section{B. Saran}

1. Pencegahan terhadap pelanggaran pelanggaran pertambangan yang terjadi seharusnya menjadi kewaiban seluruh masyarakat Indonesia karena pelanggaran pelanggaran tersebut bukan hanya akan merugikan pihak - pihak yang melakukan kegiatan usaha pertambangan tapi dapat merugikan masyarakat Indonesia secara keseluruhan, oleh karena itu pemerintah perlu mengajak masyarakat untuk ikut serta dalam menjaga dan mengawasi kegiatan pertambangan yang ada dan melaporkan apabila terdapat pertambangan yang bermasalah.

2. Pemerintah harus lebih giat lagi dalam melakukan sosialisasi mengenai peraturan pertambangan Provinsi Sulawesi Utara dan Undang - Undang Minerba kepada seluruh masyarakat sehingga masyarakat khususnya masyarakat sekitar area tambang yang sering melakukan pertambangan illegal agar dapat mengetahui dampak dampak apa yang akan terjadi apabila masyarakat sektar melakukan kegiatan pertambangan illegal dan hukuman apa yang akan diberikan bagi pelaku usaha pertambangan yang melanggar dan melakukan tindakan pidana dalam usaha pertambangan. Kemudian pembinaan dan pengawasan oleh pemerintah Provinsi Sulawesi Utara terhadap usaha pertambangan di Sulawesi Utara harus dilakukan lebih sering dan lebih teliti lagi agar pelanggaran pertambangan yang ada dapat dikurangi hingga tidak terdapat pelanggaran pertambangan lagi di Sulawesi Utara.

\section{DAFTAR PUSTAKA}

Afri Gultom, Obbie. (2014, 23 April). Sejarah Hukum Pertambangan di Indonesia. Diakses pada 21 Oktober 2019, dari www.gultomlawconsultants/sejarahhukum-pertambangan-di-indonesia.

CNN Indonesia. (2019, 5 Maret). Pemda Sulut Akui Sulit Berantas Tambang Ilegal. Diakses pada 15 November 2019, dari https://www.cnnindonesia.com/ekonomi/ 20190304183649-85-374460/pemdasulut-akui-sulit-berantas-tambang-ilegal.

Detiknews. (2004, 10 November). Cukup bukti pemerintah \& Newmont telah cemari Buyat. Diakses pada, 18 Januari 2020, dari http://news.detik.com/berita/239260/cuk up-bukti-pemerintah-newmont-cemaribuyat.

Liputan6.com. (2019, 27 Februari). Tambang Emas yang Longsor di Sulut Beroperasi Ilegal. Diakses pada, 25 Oktober 2019, dari

https://www.liputan6.com/bisnis/read/39 05168/tambang-emas-yang-longsor-disulut-beroperasi-ilegal.

Literasi Publik. (2018, 28 Agustus). Tahapan Kegiatan Pertambangan. Diakses pada 18 November 2019, dari https://www.literasipublik.com/tahapankegiatan-pertambangan.

ManadoLine. (2018, 22 November). Kekayaan alam Mitra 'Dirampok' banyak perusahaan tambang emas illegal. Dikases pada 18 Januari 2020, dari https://manadoline.com/kekayaan-alammitra-dirampok-banyak-perusahaantambang-emas-ilegal/.

Rafsanjani, Helmy. (2017, 2 November). Rekam Jejak Sejarah Pertambangan di Indonesia.Diakses pada, 18 November 2019, dari https://newswatara.com/sejarah/rekamjejak-sejarah-pertambangan-di-indonesia. Salim HS, Haji. 2017. Hukum Pertambangan di Indonesia. Depok: Rajawali Pers.

Sutedi, Adrian. Tarmizi (Ed). 2012. Hukum Pertambangan. Jakarta: Sinar Grafika.

Soekanto, Soerjono dan Sri Mamudji. 2013. Penelitian Hukum Normatif. Jakarta: RajaGrafindo Persada.

Tribun Bolmong. (2019, 14 Maret). Bolmong Miliki Ratusan Lokasi Tambang Emas, 
hanya 4 Memiliki Izin. Diakses pada 18 November, dari https://manado.tribunnews.com/2019/03/ 14/bomong-miliki-ratusan-tambang-emashanya-4-memiliki-izin.

Tribun Sulut. (2019, 27 Februari). Daftar Perusahaan Tambang Beroperasi di Sulawesi Utara, Ternyata Sulut 'Surga' Tambang Emas. Diakses pada, 13 November 2019, dari https://manado.tribunnews.com/amp/20 19/02/27/daftar-perusahan-tambangberoperasi-di-sulawesi-utara-ternyatasulut-surga-tambang-emas.

Wahyudi Hertanto, Ari. "Tanpa Tahun". Kontrak Karya (Suatu Kajian Hukum Keperdataan). Diakses pada 4 Oktober 2019, dari http://jhp.ui.ac.id/index.php/home/article /download/167/105.

\section{Peraturan Perundang - undangan :}

Kitab Undang - Undang Hukum Perdata, Buku 3 pasal 1338.

Peraturan Daerah Provinsi Sulawesi Utara Nomor 3 Tahun 2019 tentang Pertambangan Mineral.

Peraturan Pemerintah Nomor 27 Tahun 1980 tentang Penggolongan Bahan - Bahan Galian.

Peraturan Pemerintah Nomor 75 Tahun 2001 tentang Perubahan Kedua Atas Peraturan Pemerintah Nomor 32 Tahun 1969 tentang Pelaksanaan Undang Undang Nomor 11 Tahun 1967 tentang Ketentuan - Ketentuan Pokok Pertambangan.

Undang - Undang Dasar Negara Republik Indonesia Tahun 1945.

Undang - Undang Nomor 4 Tahun 2009 tentang Pertambangan Mineral dan batubara.

Undang - Undang Nomor 11 Tahun 1967 tentang Ketentuan - Ketentuan Pokok Pertambangan.

Undang - Undang Nomor 32 Tahun 2009 tentang Perlindungan dan Pengolahan Lingkungan Hidup. 